\title{
EFFECTS OF PERCEIVED CORPORATE SOCIAL RESPONSIBILITY PRACTICES ON CUSTOMERS' SATISFACTION AND PERCEIVED VALUE - A STUDY IN THE FOOD INDUSTRY IN VIETNAM
}

\author{
LE THI THANH XUAN \\ Ho Chi Minh City University of Technology, Vietnam National University HCMC \\ lttxuan@hcmut.edu.vn \\ TRAN TIEN KHOA \\ International University, Vietnam National University HCMC - ttkhoa@ hcmiu.edu.vn \\ NGUYEN PHAM NHU AN \\ Ho Chi Minh City University of Technology, Vietnam National University HCMC \\ nhu.anguyenn@gmail.com
}

(Received: April 24, 2017; Revised: October 09, 2017; Accepted: October 31, 2017)

\begin{abstract}
The main purpose of this study is to investigate the effects of perceived Corporate Social Responsibility (CSR) practices on customers' satisfaction and perceived value. According to the result of the literature review, the studied CSR practices include environmental protection, customer protection, community, HR policies, price, product quality, relationship selling, empathy, and fulfil expectations. To address the research objective, the present study proposed two following research questions: (1) What are factors of CSR practices impacting customers' satisfaction?; and (2) How do these factors influence customer satisfaction and perceived value? The study approached 236 customers of the food industry to conduct a survey empirically and tested the proposed hypotheses using structure equation modeling. The research findings show that (1), in Vietnamese customers perceptions, Perceived price, Perceived quality and Empathy are three components of CSR practices; (2) these components have positive impacts on Customer satisfaction; and (3) Customer satisfaction have a positive relation with customers' perceived value. These findings help to enrich the CSR literature in developing countries like Vietnam, and to confirm the findings of previous studies. Moreover, from the research findings, the present study suggested some managerial implications for firms in the food industry relating to price, product quality and empathy.
\end{abstract}

Keywords: Corporate social responsibility; Customers' satisfaction; Food industry; Perceived value; Vietnam.

\section{Introduction}

Corporate social responsibility (CSR) is not a new concept in both academic and practical field. It has been developed from 1950 s by the first definition documented by Bowen in 1953 (Carroll, 1999). Even though CSR was first introduced in Vietnam in 2003 (Hamm, 2012), Vietnamese business organizations have faced many difficulties in understanding this concept in practice and as a result, the implementation is still limited. There are many voices from business that CSR is government's concerns, but firms'; and most of firms have considered CSR is a type of cost, not benefit (Thoa Nguyen, 2010).
Perhaps, that is the reasons of many scandals of the environment and product quality, such as Formosa in 2016, Tan Hiep Phat in 2015 and many other scandals.

Empirically, researchers have found impacts of CSR on many aspects in firms (Shin \& Thai, 2015), such as CSR and financial performance, CSR and marketing activities, or CSR and customer behaviors. In particular, there are studies exploring the relationship between CSR and socially responsible marketing activities (Quazi \& O'Brien, 2000; Walsh \& Bartikowski, 2013). The findings of previous studies show that CSR practices can help to improve business 
performance if consumers positively evaluate CSR practices and this will lead them to choose to buy products/services (Loureiro, Dias Sardinha, \& Reijnders, 2012). Moreover, scholars also found evidences of the role of customer satisfaction in this issue (Saeidi, Sofian, Saeidi, Saeidi, \& Saaeidi, 2015). When customers are satisfied and loyal, they will buy more and are willing to pay more and recommend more (Martínez \& Rodríguez del Bosque, 2013).

Even though many studies found positive effects of CSR on firm performance, other scholars also empirically found that the relations between CSR practices and firm performance are not positive as mentioned. One of these findings is about the weak influence of CSR on financial performance and stock returns (Nelling \& Webb, 2008). Echoing with the findings of Nelling and Webb (2008), Surroca, Tribo, \& Waddock (2010) also found there is no direct relationship between CSR and financial performance. Similarly, Demacarty (2009) concluded in his study that responsibility or irresponsibility will bring financial returns equally. Moreover, (Inoue \& Lee (2011) disaggregated CSR into five dimensions, including employee relation, product quality, community relations, environmental issues and diversity issues, to evaluate the impact of these components on firm performance. In their findings, community attentions of firms, environmental and diversity issues have a negative effect or do not have positive impact on financial performance.

From literature evidences, obviously, the influence of CSR practices on firm performance is still a question. Even though scholars have been tried to investigate the role of CSR in aspects of marketing activities, the result of reviewing literature shows that CSR and customer satisfaction is not adequately explored. Furthermore, the findings of previous studies are not convergent. Some studies reject the positive relations between CSR practices and customer loyalty and satisfaction (Carrigan and Attalla 2001, cited in Pérez \& Bosque, 2015). Therefore, it is clear that more studies need to be conducted to clearly identify the importance of CSR practices and its effect on consumers' satisfaction.

Based on this rationale, the purpose of the present study is to answer the following to research questions: (1) What are factors of CSR practices of food companies impacting customers' satisfaction?; and (2) How do these factors influence customer satisfaction and their perceived value?

\section{Literature review}

\subsection{Corporate social responsibility and its importance to firms}

The concept of CSR has attracted researchers' attention for a very long time. However, after 1950s, the literature of CSR is rapidly enriched by many studies in theory and practice as well (Carroll, 1999; Dahlsrud, 2006). There are many studies which define the concept of CSR, and the controversial on how to define CSR is still continuing (Xuan \& Teal, 2011). For example, CSRwire provides a CSR definition as follows "CSR is defined as the integration of business operations and values, whereby the interest of all stakeholders including investors, customers, employees and the environment are reflected in the company's policies and actions." (2003, cited in Dahlsrud, 2006). Or, Kotler \& Lee (2005) define CSR as: "A commitment to improve community well-being through discretionary business practices and contributions of corporate resources". Among CSR definitions, the one developed by Carroll $(1979,1991)$ is the most- widely accepted and employed in academic and practical studies (Nalband \& Kelabi, 2014; Xuan \& Teal, 2011) because it can integrate all existing aspects and cover other concepts of CSR (Ramasamy \& Yeung, 2009).

In his paper, Carroll (1979, p. 500) documented a CSR definition consisting of four responsibilities categories: economic, legal, ethical and discretionary expectations (which is revised as philanthropic expectation in the study in 1991): 
The social responsibility of business encompasses the economic, legal, ethical, and discretionary expectations that society has of organizations at a given point in time (Carroll 1979, p.500)

According to Freeman (1984), CSR helps to enhance value not only for firms, customer, but also for employees and other stakeholders. The findings of many empirical studies affirmed this point. Many scholars found that practicing CSR has a positive impact not only on financial performance, corporate reputation but also on the ability to attract candidates, or improving employee loyalty and working behaviors (Bolton \& Mattila, 2015; Mandhachitara \& Poolthong, 2011; Nha \& Xuan, 2014; Sen \& Bhattacharya, 2001). Even though most of the studies conducted in advanced economies, ones undertaken in emerging economies also found that CSR practices has a positive and significant impact on market valuation (Cheung, Tan, Ahn, \& Zhang, 2010). Additionally, CSR practices towards employees, customers, suppliers become a complementary input to a better financial performance (Cavaco \& Crifo, 2014). Significantly, CSR plays an important role in satisfying customers' demand and requirements. CSR implementation in marketing activities helps to enhance consumers' evaluation about the company (Inoue \& Kent, 2014). In short, CSR has a positive impact on aspects of business performance. In particular, engaging in CSR should be prioritized by managers and practitioners to attract customer.

\subsection{The effects of CSR practices on customers' satisfaction}

Studies on CSR not only focus on how it impacts on business performance in general, but also on some specific aspects, such as human resource, marketing (Sen \& Bhattacharya, 2001). Especially, researchers have focused explicitly on consumers' reaction to CSR and firm's CSR record on consumers' evaluation of that company and its products/services (Brown and Dacin, 1997, cited in Sen \& Bhattacharya, 2001).
Consumers' evaluation is the basic for their satisfaction. According to Anderson, Fornell and Mazvanchery (2004, cited in Luo \& Bhattacharya, 2006), customer satisfaction is their evaluation when they buy and consume products or service. A number of studies have found that customer satisfaction, the value perceived by consumers and market value interrelate with each other positively (Loureiro et al., 2012; Luo \& Bhattacharya, 2006).

There are at least three streams to explain the reason CSR practices of a firm that lead to greater customer satisfaction (Luo \& Bhattacharya, 2006). Firstly, based on stakeholder theory and institutional theory, actions of a firm are interesting to customers (Handelman and Arnold, 1999 cited in Luo \& Bhattacharya, 2006). Therefore, firms have to consider carefully their expectations, and customers are likely to be more satisfied if the company is more socially responsible. Secondly, many scholars have found empirical evidences to illustrate that a strong CSR record helps to boost consumers' evaluations of and attitudes towards the firm (Sen \& Bhattacharya, 2001). In other words, consumers are likely to be satisfied with what a firm offers. The last one is about one antecedent of customer satisfaction perceived value. Through practicing CSR, firm can improve customer knowledge of specific issue, and this drives to enhance customer satisfaction (Luo \& Bhattacharya, 2006)

Previous scholars have found direct relationship between CSR practice and customer satisfaction (Luo \& Bhattacharya, 2006; Peters, 2005; Shin \& Thai, 2015). By empirical evidence, these research findings showed that a firm's CSR initiatives could increase customer satisfaction. Studies also found that consumers are considered as the most important stakeholder group affecting the ways CEOs manage social expectations (Loureiro et al., 2012). This point once confirms the importance of the need to study the link between CSR practice perceived by customers and their satisfaction. 


\subsection{Components of consumers' evaluation of CSR practices}

Environmental responsibility is considered as "the duty to cover environmental implication of the company's operations, products and facilities, eliminate waste and emissions, maximize the efficiency and productivity of its resources, and minimize practices that might adversely affect the enjoyment of the country's resources by future generations" (Mazurkiewicz, 2004 in p2 cited in Rahman \& Post, 2012). Due to the situation of unclear regulations, environmental responsibility is classified as both of compliant and preventive activities. Even though firms' roles in the environment are still debating, environmental aspect is a primary component of CSR (McDonald \& Rundle-Thiele, 2008; Singh, 2009) and it is customers' attention and has impact on customers' satisfaction (Chung, Yu, Choi, \& Shin, 2015; Loureiro et al., 2012; McDonald \& Rundle-Thiele, 2008; Sen \& Bhattacharya, 2001). Therefore, a positive relationship between environmental protection and customer satisfaction is proposed (Hla).

According to stakeholder theory (R. E. Freeman, 1984), customers are an important stakeholder impacting on firm's economic benefits. In their study, Murray and Vogel (1997, cited in McDonald \& Rundle-Thiele, 2008) investigated that practices of CSR impacting consumers also include consumer protection. That is the reason used to explain why a company's efforts in consumer protection have a direct and positive influence on company evaluation (McDonald \& Rundle-Thiele, 2008; Pérez \& Bosque, 2015; Sen \& Bhattacharya, 2001). Obviously, therefore, consumer protection - one of CSR practices - has a positive impact on their satisfaction (H1b).

Philanthropic responsibility is one in four categories of responsibilities in CSR pyramid which includes a company's contribution to the community and to improve quality of life (Carroll, 1991). Plewa, Conduit, Quester, \& Johnson (2015) empirically found that voluntary activities to serve the community of a firm are considered as a CSR initiative and importantly, there is a positive response to a company's products/services from consumers who value these activities. Similarly, other studies also found the positive impact of philanthropic responsibility on consumer satisfaction (Chung et al., 2015; Loureiro et al., 2012). For these reasons, there is a positive impact of philanthropic responsibility on consumer satisfaction (HIc).

Freeman (1984) also identified employees as one significant stakeholder having a crucial impact on a firm's performance. The way employees are treated significantly impacts their experiences, attitudes, behaviors, and satisfaction. Employees are ones who produce products/services, communicate with customers and deliver CSR values to customers. Studies have found that customers' attitudes towards the firm and its products/services are affected by what employees experience and practice (Loureiro et al., 2012; Pérez \& Bosque, 2015; Schneider \& Bowen, 1985). Based on this review, the hypothesis about the positive impact of labour practices (or employee treatment) on customer satisfaction is proposed (HId).

Perceived price is also a consideration of consumers when they are aware of CSR activities of a firm. According to Carroll (1979, 1991), a firm can make an acceptable profit based on its goods and service that customers need and want. It means that customers can accept a fair price as compared with products' or services' quality. Loureiro, et al. (2012) found a positive effect of perceived price on customer satisfaction. Based on previous studies, therefore, there is a positive impact of Perceived price on customer satisfaction (Hle).

Perceived quality is also mentioned and analysed by Carroll $(1979,1991)$ as one responsibility in CSR pyramid which is classified "Economic responsibility". In his paper, Carroll (1991) explained clearly that goods and services need to meet consumers' needs and wants. Many previous studies have found empirically the positive impact of 
Perceived quality on customer satisfaction (Chung et al., 2015; Loureiro et al., 2012; Luo \& Bhattacharya, 2006; Mandhachitara \& Poolthong, 2011). Obviously, the positive influence of Perceived quality on customer satisfactions is proposed (Hlf).

The following CSR activity is Empathy. Parasuraman, Zeithaml, \& Berry (1988, p. 23) explained Empathy as follows "Caring, individualized attention the firm provides its customers". In their study, Loureiro, et al. (2012) empirically affirmed the positive effect of Empathy (Relationship selling) considered as one of CSR activities on customer satisfaction. Adopted from previous studies, the hypothesis of positive impact of Empathy on customer satisfaction is proposed $(\mathrm{Hlg})$.

Lastly, fulfilling expectations of stakeholder is also a CSR activity that a firm needs to practice. As analysed by Carroll (1991), firms need to know who their stakeholders are, what their stakes are; and firms need to prepare strategies, actions or decisions to best deal with responding stakeholders' expectations. Similarly, Loureiro, et al. (2012) found the evidence empirically in the automobile industry that fulfilling expectations have a positive relations on customer satisfaction. Therefore, in the present study, the hypothesis of positive impact of Fulfilling expectations on customer satisfaction is proposed (H1h).

\subsection{Customer satisfaction and perceived value}

Most of the studies found the positives impact of perceived value on customer satisfaction. However, from another perspective, Loureiro, et al. (2012) hypothesized and empirically affirmed the effect of customer satisfaction on perceived value. In their study, perceived value is a consequence of customer satisfaction. Based on empirical data, Loureiro et al. (2012) concluded that the relation between customer satisfaction and perceived value is two-way and both can contribute to each other.

The present study employs this research finding and proposes the hypothesis 2 (H2): There is a positive impact of customer satisfaction on perceived value.

The literature review results in the conceptual framework as presented in Figure 1.

\section{Components of CSR practices}
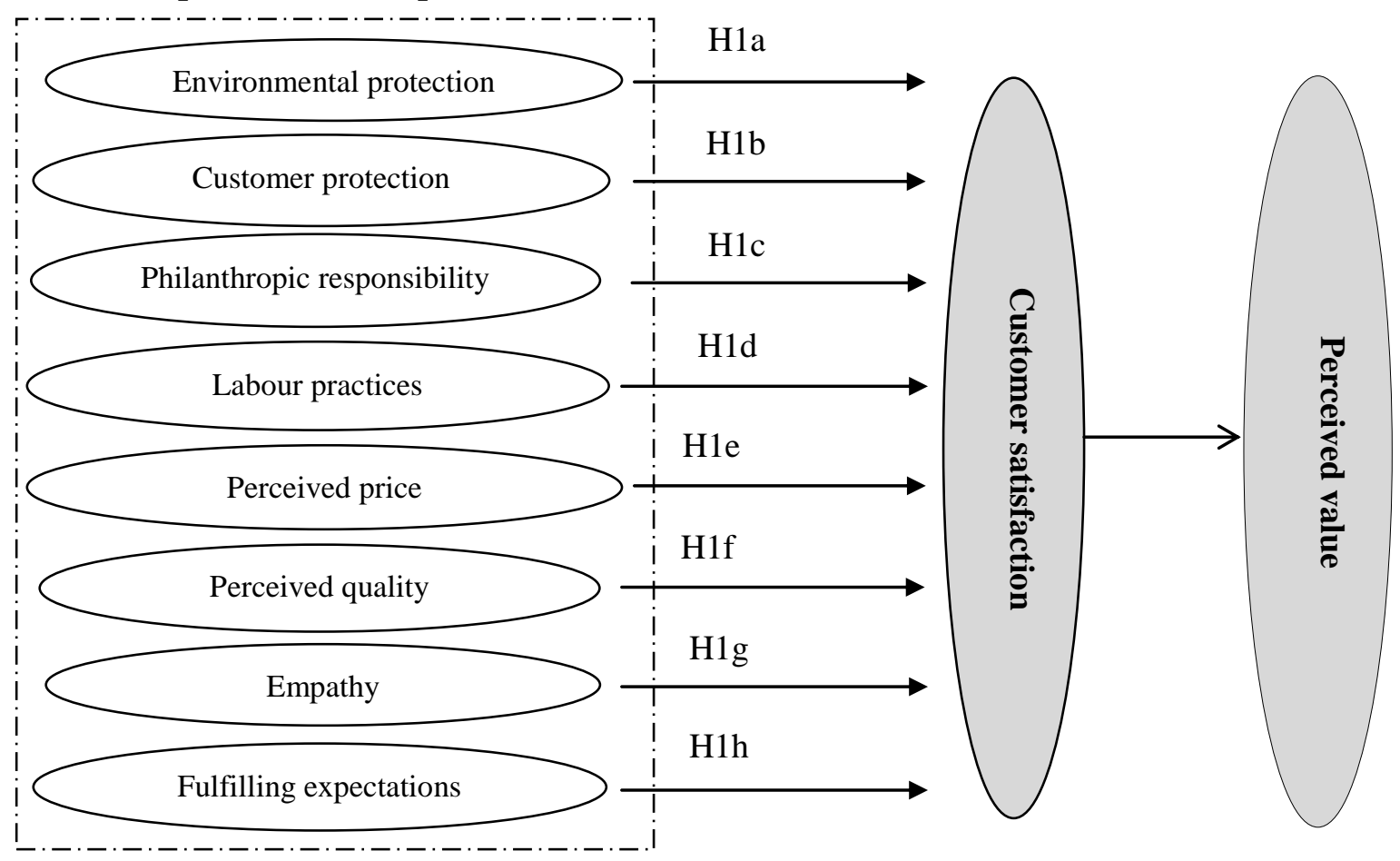

Figure 1. Proposed conceptual framework of the present study 


\section{Methodology}

\subsection{Measurement adjustment}

The items to measure the constructs in the research model are adapted from the previous studies, such as Loureiro et al (2012), Chung et al. (2015). Then, a preliminary study was undertaken to revise the scale to be appropriate for the present research context. There are two in-depth interviews with two experts of the food industry and 01 focus group with 06 consumers conducted. The qualitative result shows that two over eight constructs of CSR components (Environmental protection and Labour practices) were eliminated due to lacking of information. Participants in the focus group explain that they do not have information about how firms treat their employees and their environmental policies. What they know of these issues is via media only; therefore they cannot evaluate items in these factors.

Finally, the measurement consists of 8 constructs with 29 items. The construct "Perceived value" based on Loureiro et al (2012) is measured by three items, including (a) PV1 - Product of this firm is the best in the industry, (b) PV2 - Apparently, I am practicing CSR with this firm when purchasing and consuming its product, and (c) PV3 -I feel proud when purchasing and consuming product of this firm.

There are four items to measure "Customer satisfaction" adapted from Chung et al (2015), namely (a) CS1 - The CSR policies of this firm meets my expectations, (b) CS2 - Overall, I am satisfied with CSR policies of this firm, (c) CS3 - Overall, I am satisfied with product of this firm and (d) Overall, I am satisfied with the service of this firm.

The six components of CSR practices consist of 3 items (FE1, FE2, FE3) for Fulfilling expectations, 4 items (EMPA1, EMPA2, EMPA3, EMPA4) for Empathy, 3 items (P_QUAL1, P_QUAL2, P_QUAL3) for Perceived quality, 4 items (P_PRICE1,
P_PRICE2, P_PRICE3, P_PRICE4) for Perceived price, 4 items (PHILA1, PHILA2, PHILA3, PHILA4) for Philanthropic responsibility, 4 items (CUS1, CUS2, CUS3, CUS4) for Customer protection.

\subsection{Sampling and data collection}

A questionnaire is prepared to collect data. At first, the questionnaire is revised by a preliminary study with in-depth interview and focus group as the main method to collect respondents' opinions. Then, the final questionnaires were directly delivered to consumers of the food industry, who are over 18 at supermarkets, food stores like Vissan, Coop Food, ... Emails and social networks are also used as the means to approach respondents. Therefore, convenient sampling is chosen.

\subsection{Data analysis}

The Principle component method with Promax rotation in exploratory factor analysis (EFA technique) are used. Before applying the EFA method, the reliability of the scales has been tested by using Cronbach's alpha criteria, it should be at least 0.6 to be accepted (Nunnally, 1994). Then, EFA technique is applied with data exploration and variable reduction steps. The EFA process is accepted with the threshold of KMO measure higher than 0.5 and Bartlett's Test of Sphericity significant at 5\%, Eigen values must be larger than 1, Factor loadings of each variable should be at least 0.5 and no any crossloading that is different more than 0.3 (Hair, Tatham, Anderson, Black, \& Babin, 2006). Finally, a structural equation model approach is employed to test the relationships in the present study.

\section{Research findings}

After cleaning and deleting missing cases, the final data of 236 respondents has been used for analysis. The percentage of men and women in valid sample are 90 and 146. Most of respondents are in the age of 25-34 with 45.3 percent, there are 26.7 and $22.5 \%$ percent for the age of $18-25$ and $35-44$, respectively; 
and 5.5 percent for over 45. In terms of occupation, 36.9 ad 40.7 percent of respondents are staff-officer and engineers; 20 of them are teachers with 8.5 percent, and other occupation take account of 33 respondents with 14 percent. In respect of income, most of participants earn less than 7 million VND (41.1 percent lower than 5 million, and 29.2 percent lower than 7 million VND). Among 30 percent of respondents earning over 7 million VND, there are 37 respondents (15.7percent) who can earn over 10 million VND per month.

\subsection{Validity and reliability of measures}

Testing the reliability of the scales, all 6 factors - components of CSR practices - have the value of the Cronbach's Alpha from 0.676 (for Customer protection) to 0.874 (for Fulfilling expectations), satisfy the condition mentioned in Methodology. Thanks to eliminating only one variable (CUS3 $=0.049$ ) from Customer protection, its Cronbach's Alpha reaches to 0.829. Cronbach's Alpha of Customer satisfaction and Perceived value are 0.768 and 0.822 , respectively.

Next, all items (except CUS3) were analysed by confirmatory factor analysis (CFA) using AMOS to assess the measurement model representing relations among all constructs and their associated items. After twice of CFA analysis, 4 items (EMPA4, P_PRICE3, PHILA1, and CS1) were eliminated. Finally, CFA of the measurement model including 24 items yielded the following measures Chi-square $\chi 2$ $(\mathrm{df}=224)=420.769 ; \mathrm{p}=.000(<0.05)$; Normed chi-square $\chi 2 / \mathrm{df}=1.878$; Goodnessof-fit index GFI = 0.880; Tucker-Lewis index $\mathrm{TLI}=0.915$; Comparative fit index CFI = 0.931; Root mean square error of approximation RMSEA $=0.061$. It was also noted that no offending estimates were found (i.e., no negative error variances or Heywood cases) (Hair et al., 2010). All these statistics showed that the measurement model fits the data set in this empirical study.
In addition, all item loadings on their designate constructs range from 0.64 to 0.98 and AVE of scales ranged from 0.61 to 0.70 , which were all above 0.5, indicating satisfactory convergent validity (Tho and Trang, 2011). Correlation coefficients between pairs of constructs ranged from 0.06 to 0.41 . The squares of which were from 0.004 to 0.169 , indicating discriminant validity of scales. Composite reliabilities were from 0.823 to 0.880 (which should be minimum at 0.7 , Thọ and Trang, 2011). Thus, convergent validity, discriminant validity and reliability of scales are satisfactory.

\subsection{Structural model estimation and hypothesis testing}

Given the satisfactory fit of the measurement model, the proposed hypotheses were then tested using structural equation modeling (see Figure 1). In this model, Perceived value was specified as multidimensional reflective constructs, while Customer satisfaction, Fulfilling expectations, Perceived price, Empathy, Customer protection, Philanthropic responsibility, Perceived quality were unidimensional constructs. The estimation of the proposed structural model using ML method resulted in a good fit: Chi-square $=426.281 ;$ df $=230$; $\mathrm{CFI}=0.931 ;$ GFI $=0.878 ;$ TLI $=0.917$; RMSEA $=0.060$.

Based on the standardized path coefficients and $\mathrm{p}$ value, four over seven hypotheses H1c, H1d, H1e, and $\mathrm{H} 2$ were supported (at $\mathrm{p}=<0.05$ ). Perceived price, Perceived quality and Empathy have significantly positive impacts on Customer satisfaction, and then, Customer satisfaction has a positive impact on Perceived value. However, other three hypotheses H1a, H1b, H1f were not supported. In this research model, three factors Perceived price, Perceived quality and Empathy have no direct impact on Perceived value. They only influence Customer satisfaction that leads to influence on Perceived value. 


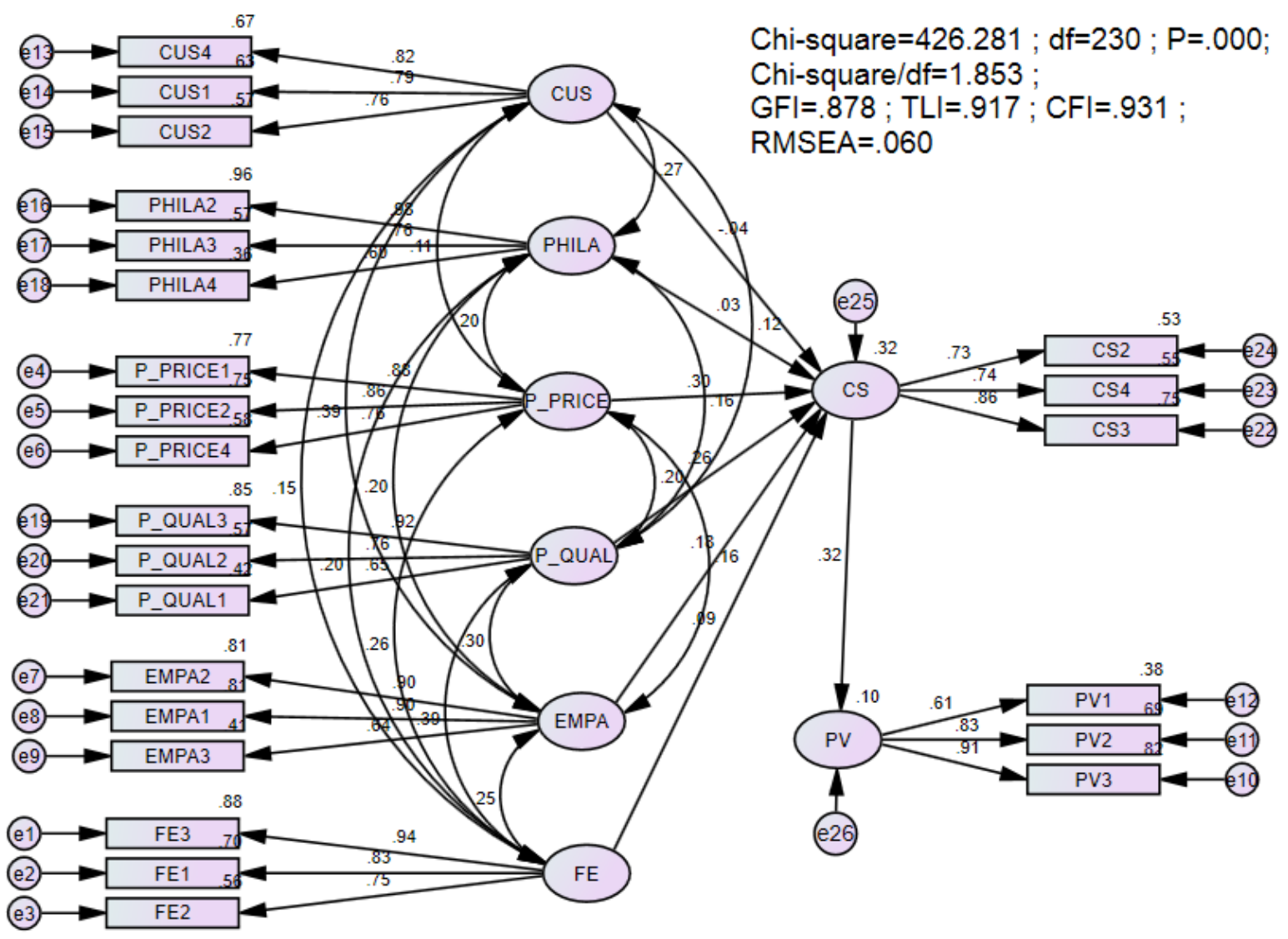

Figure 2. Amos estimation results

Table 1

Amos estimation results

\begin{tabular}{|c|c|c|c|c|c|}
\hline Hypothesis & & Path & SE & $\mathbf{P}$ & Hypothesis test \\
\hline $\mathrm{H} 1 \mathrm{a}$ & CS & $<---$ CUS & 0.066 & 0.606 & Not supported \\
\hline $\mathrm{H} 1 \mathrm{~b}$ & CS & <--- PHILA & 0.052 & 0.634 & Not supported \\
\hline H1c & CS & <--- P_PRICE & 0.061 & $* * *$ & Supported \\
\hline H1d & $\mathrm{CS}$ & <--- P_QUAL & 0.058 & $* * *$ & Supported \\
\hline H1e & CS & <--- EMPA & 0.065 & 0.019 & Supported \\
\hline H1f & CS & $<---\quad$ FE & 0.048 & 0.200 & Not supported \\
\hline $\mathrm{H} 2$ & PV & $<---\quad C S$ & 0.080 & $* * *$ & Supported \\
\hline
\end{tabular}




\section{Discussion}

The research findings show that 4 over 7 proposed hypotheses are supported by the observed data in the food industry. Firstly, the present study empirically explains perceived value to be a consequence of customer satisfaction. As mentioned in the Literature Review, most of the studies found the positive impact on customer satisfaction; however, the study of Loureiro et al. (2012) is the only which proposed and empirically confirmed the opposite relation. The finding of the present study helps to re-confirm the Loureiro et al.'s findings by date in the Vietnamese food industry. This means, the more customer feels satisfied, the more favourable perception of product value they have. Especially, in the chaotic market of food sector in Vietnam, in which consumers are looking for safe sources for food as the first priority, if food companies can provide them with safe, high quality and reasonable price for safe, green and types of foods, they can be satisfied better and better perceptions of food value.

Secondly, in this study, only consumers' perceptions of 3 per $6 \mathrm{CSR}$ practices have influences on their satisfactions. Meanwhile, Customer Protection, Philanthropic responsibility and Fulfilling Expectation do not have impact or do have slight impacts on Customer Satisfaction. Among 3 CSR practices, Perceived Price, Perceived Quality and Empathy; Perceived Price has the greatest impact on Customer Satisfaction (25.5\%), which is followed by Perceived Quality with 20\%. Empathy has the lowest impact with $15.3 \%$. These findings show that, to consumers of Vietnamese food industry, price and quality - two important components of CSR - are two key factors that make them satisfied.

From the observed data, obviously, consumers do not think Customer protection affecting their satisfaction. One fact is that, even though there are many efforts of the government in promoting activities of customer protection, most of them do not know of or have any information about these activities. In an online survey with over 1,200 participants conducted by Institute of Society, Economy and Environment, 90\% of them do know any information about organizations protecting their rights (Trung-Nghia, 2015). It shows that, Vietnamese consumers do lack of knowledge of their rights in consumption. The finding of the present study also helps to explain this fact.

\section{Conclusion}

The present paper is conducted to investigate the effects of perceived Corporate Social Responsibility (CSR) practices on customers' satisfaction and perceived value. The research findings show that (1), in Vietnamese customers perceptions, Perceived price, Perceived quality and Empathy are three components of CSR practices; (2) these components have positive impacts on Customer satisfaction; and (3) Customer satisfaction has a positive relation with customers' perceived value.

Our findings have some significant contributions in implementing CSR in the food industry. Firstly, to supplement to previous studies on the importance of CSR such as its effects on financial performance (Inoue \& Lee, 2011; Lin, Yang, \& Liou, 2009) or brand equity (Wang, Chen, Yu, \& Hsiao, 2015), or on employee satisfaction (Story, Castanheira, \& Hartig, 2016), the present study found that CSR practices help to increase customer satisfaction and perceived value. This finding links managers to think of embedding CSR to their business strategies.

Secondly, as we found, Perceived price and Perceived quality are two CSR practices having crucial effects on Customer satisfaction. This finding again confirms the issues make consumer satisfied are quality and price and these are the aspects that firms always have to pay high attention to. In particular, Empathy is one of CSR practices having impact on customer satisfaction. 
Hence, managers should pay attention to sale and after sale service by training sellers and employees working in their distribution channels. These ones are important to provide good services and demonstrate their real concerns for consumers.

This study has some limitations. Firstly, two CSR practices - Environmental protection and Labour practices - were eliminated at the stage of preliminary research because participants do not have information to answer. The approaches to collect respondents are convenient, therefore they do not have information to participate the survey. Secondly, this study has the limitation of data collection. The data is collected only within Ho Chi Minh city. With that, the managerial implications would not be well-explained for the whole sector. Lastly, the present study has not conducted a qualitative study (after data analysis) to get participants' explanations about the elimination of Customer protection, Philanthropic Responsibility and Fulfilling expectations

\section{References}

Bolton, L. E., \& Mattila, A. S. (2015). How Does Corporate Social Responsibility Affect Consumer Response to Service Failure in Buyer-Seller Relationships? Journal of Retailing, 91(1), 140-153. doi: http://dx.doi.org/10.1016/j.jretai.2014.10.001

Carroll, A. B. (1979). A three dimensional conceptual model for corporate peformance. Academy of Management Review, 4(4), 497-505.

Carroll, A. B. (1991). The pyramid of corporate social responsibility: toward the moral management of organizational stakeholders. Business Horizons, 34, 39-48.

Carroll, A. B. (1999). Corporate social responsibility: evolution of a definitional construct. Business \& Society, 38(3), 268-295.

Cavaco, S., \& Crifo, P. (2014). CSR and financial performance: complementarity between environmental, social and business behaviours. Applied Economics, 46(27), 3323-3338. doi:10.1080/00036846.2014.927572

Cheung, Y., Tan, W., Ahn, H.-J., \& Zhang, Z. (2010). Does Corporate Social Responsibility Matter in Asian Emerging Markets? Journal of Business Ethics, 92(3), 401-413. doi:10.1007/s10551-009-0164-3

Chung, K.-H., Yu, J.-E., Choi, M.-G., \& Shin, J.-I. (2015). The effects of CSR on customer satisfaction and loyalty in China: The moderating role of corporate image. Journal of Economic, Business and Management, 3(5), 542-547.

Dahlsrud, A. (2006). How corporate social responsibility is defined: an analysis of 37 definitions. Corporate Social Responsibility and Environmental Management, 15(1-13).

Demacarty, P. (2009). Financial returns of corporate social responsibility, and moral freedom and responsibility of business leaders. Business and Society Review, 114(3), 393-433.

Freeman, E. R. (1984). Strategic management: a stakeholder approach: Pitman, Boston, MA.

Freeman, R. E. (1984). Strategic management: A stakeholder approach (Vol. null).

Hair, J., Joseph F.,, Tatham, R. L., Anderson, R. E., Black, W. C., \& Babin, B. J. (2006). Multivariate data analysis. Upper Saddle River, N.J.: Upper Saddle River, N.J. : Pearson Prentice Hall.

Hamm, B. (2012). Corporate Social Responsibility in Vietnam: Integration or Mere Adaptation? Pacific News, 38, 4-8.

Inoue, Y., \& Kent, A. (2014). A Conceptual Framework for Understanding the Effects of Corporate Social Marketing on Consumer Behavior. Journal of Business Ethics, 121(4), 621-633. doi: http://dx.doi.org/10.1007/s10551-013-1742-y

Inoue, Y., \& Lee, S. (2011). Effects of different dimensions of corporate social responsibility on corporate financial performance in tourism-related industries. Tourism Management, 32(4), 790-804. doi:

http://dx.doi.org/10.1016/j.tourman.2010.06.019 
Kotler, P., \& Lee, N. (2005). Corporate social responsibility-Doing the most good for your comapny and your cause. Hoboken, New Jersey: John Wiley \& Sons, Inc.

Lin, C.-H., Yang, H.-L., \& Liou, D.-Y. (2009). The impact of corporate social responsibility on financial performance: Evidence from business in Taiwan. Technology in Society, 31, 56-63.

Loureiro, S. M. C., Dias Sardinha, I. M., \& Reijnders, L. (2012). The effect of corporate social responsibility on consumer satisfaction and perceived value: the case of the automobile industry sector in Portugal. Journal of Cleaner Production, 37(0), 172-178. doi:http://dx.doi.org/10.1016/j.jclepro.2012.07.003

Luo, X., \& Bhattacharya, C. B. (2006). Corporate Social Responsibility, Customer Satisfaction, and Market Value. Journal of Marketing, 70(4), 1-18.

Mandhachitara, R., \& Poolthong, Y. (2011). A model of customer loyalty and corporate social responsibility. Journal of Services Marketing, 25(2), 122-133. doi:doi:10.1108/08876041111119840

Martínez, P., \& Rodríguez del Bosque, I. (2013). CSR and customer loyalty: The roles of trust, customer identification with the company and satisfaction. International Journal of Hospitality Management, 35(0), 8999. doi:http://dx.doi.org/10.1016/j.ijhm.2013.05.009

McDonald, L. M., \& Rundle-Thiele, S. (2008). Corporate social responsibility and bank customer satisfaction: A research agenda. International Journal of Bank Marketing, 26(3), 170-182. doi: doi:10.1108/02652320810864643

Nalband, N. A., \& Kelabi, S. A. (2014). Redesigning Carroll's CSR pyramid model. Journal of Advanced Management Science, 2(3).

Nelling, E., \& Webb, E. (2008). Corporate social responsibility and financial performance: the "virtuous circle" revisited. Rev Quant Finan Acc, 32, 197-209.

Nha, N. P. T., \& Xuan, L. T. T. (2014). Consumers' perceptions of Corporate social responsibility and Purchasing intention - A study in the electronic sector. Journal of Science (Open University), 3(36), 60-79.

Nunnally, J. C., \& Bernstein, I. H. (1994). Psychometric theory (3rd ed.): McGraw Hill.

Parasuraman, A., Zeithaml, V. A., \& Berry, L. L. (1988). Servqual: A Multiple-Item Scale For Measuring Consumer Perc. Journal of Retailing, 64(1), 12.

Pérez, A., \& Bosque, I. R. d. (2015). Corporate social responsibility and customer loyalty: exploring the role of identification, satisfaction and type of company. Journal of Services Marketing, 29(1), 15-25. doi:doi:10.1108/JSM-10-2013-0272

Peters, M. (2005). CSR is a consumer concern. Consumer Policy Review, 15(2), 36-37.

Plewa, C., Conduit, J., Quester, P. G., \& Johnson, C. (2015). The Impact of Corporate Volunteering on CSR Image: A Consumer Perspective. Journal of Business Ethics, 127(3), 643-659. doi:http://dx.doi.org/10.1007/s10551014-2066-2

Quazi, A. M., \& O'Brien, D. (2000). An empirical test of a cross-national model of corporate social responsibility. Journal of Business Ethics, 25(1), 33-51.

Rahman, N., \& Post, C. (2012). Measurement Issues in Environmental Corporate Social Responsibility (ECSR): Toward a Transparent, Reliable, and Construct Valid Instrument. Journal of Business Ethics, 105(3), 307-319. doi:http://dx.doi.org/10.1007/s10551-011-0967-x

Ramasamy, B., \& Yeung, M. (2009). Chinese consumers' perception of corporate social responsibility. Journal of Business Ethics, 88, 119-132.

Saeidi, S. P., Sofian, S., Saeidi, P., Saeidi, S. P., \& Saaeidi, S. A. (2015). How does corporate social responsibility contribute to firm financial performance? The mediating role of competitive advantage, reputation, and customer satisfaction. Journal of Business Research, 68(2), 341-350. doi: http://dx.doi.org/10.1016/j.jbusres.2014.06.024

Schneider, B., \& Bowen, D. E. (1985). Employee and customer perceptions of service in banks: Replication and extension. Journal of Applied Psychology, 70(3), 423-433. doi:10.1037/0021-9010.70.3.423 
Sen, S., \& Bhattacharya, C. B. (2001). Does doing good always lead to doing better? Consumer reactions to corporate social responsibility. Journal of Marketing Research, XXXVIII, 225-243.

Shin, Y., \& Thai, V. V. (2015). The Impact of Corporate Social Responsibility on Customer Satisfaction, Relationship Maintenance and Loyalty in the Shipping Industry. Corporate Social Responsibility and Environmental Management, 22(6), 381-392. doi:10.1002/csr.1352

Singh, N. (2009). Exploring socially responsible behaviour of Indian consumers: an empirical investigation. Social Responsibility Journal, 5(2), 200-211. doi:http://dx.doi.org/10.1108/17471110910964487

Story, J., Castanheira, F., \& Hartig, S. (2016). Corporate social responsibility and organizational attractiveness: implications for talent management. Social Responsibility Journal, 12(3), 484-505. doi:doi:10.1108/SRJ-072015-0095

Surroca, J., Tribo, J. A., \& Waddock, S. (2010). Corporate responsibility and financial performance: the role of intangible resource. Strategic Management Journal, 31, 463-490.

Thoa Nguyen, N. (2010). Opportunities from CSR from SMEs. The Saigon Times.

Trung-Nghia. (2015, 12 Mar 2015). 90\% of consumers do not know about organizations protecting their rights. Nguoi Dong Hanh.

Walsh, G., \& Bartikowski, B. (2013). Exploring corporate ability and social responsibility associations as antecedents of customer satisfaction cross-culturally. Journal of Business Research, 66(8), 989-995. doi:http://dx.doi.org/10.1016/j.jbusres.2011.12.022

Wang, D. H.-M., Chen, P.-H., Yu, T. H.-K., \& Hsiao, C.-Y. (2015). The effects of corporate social responsibility on brand equity and firm performance. Journal of Business Research, 68(11), 2232-2236. doi: http://dx.doi.org/10.1016/j.jbusres.2015.06.003

Xuan, L. T. T., \& Teal, G. (2011). A development in defining Corporate Social Responsibility. Journal of Science and Technology Development, 14(2), 106-115. 